\section{Seed Ratios for Optimum Turf Quality of Mixtures of Kentucky Bluegrass, Creeping Red Fescue, and Alkaligrass Subjected to Deicing Salts}

\author{
Longyi Yuan ${ }^{1}$, Deying $\mathrm{Li}^{2,3}$, Yang $\mathrm{GaO}^{2}$, and Wenjing Xiao ${ }^{1}$
}

AdDitionAl INDEX WORDs. road side, salinity, seed mixture, turfgrass

SuMMARY. Deicing salts often are applied to sidewalks and roadways to enhance pedestrian and driving safety during freezing weather. For example, in eastern North Dakota, average annual snow days and amount are 29 days and 40 inches, respectively. This study was conducted in Fargo, ND, to investigate the population dynamics of turfgrass mixtures composed of kentucky bluegrass [KB (Poa pratensis)], creeping red fescue [RF (Festuca rubra)], and alkaligrass [ALK (Puccinellia sp.)] with the goal of optimizing turf quality by selecting seed ratios containing these species in home lawn mixtures and subject to frequent applications of deicing salts. A total of 21 mixtures were generated based on simplex-lattice design with $\mathrm{KB}, \mathrm{ALK}$, and RF contributing to $0 \%, 20 \%, 40 \%, 60 \%, 80 \%$, and $100 \%$ of their respective full-seeding rate of 150,150 , and $300 \mathrm{lb} /$ acre, respectively, after pure live seed (PLS) adjustment. The mixtures were tested at annual deicing salt rates of $0,160,320 \mathrm{lb} / \mathrm{acre}$, which represent typical application. The results showed that the botanical component of the stands of grasses shifted over a 2 -year period for all salt levels. Despite the good salinity tolerance of ALK reported elsewhere, it did not contribute to the improvement of turf quality in mixtures receiving deicing salts at $320 \mathrm{lb} /$ acre per year. Therefore, ALK is not recommended for lawn, but mixing KB and $\mathrm{RF}$ in $\mathbf{4 8 \%}$ and $52 \%$ of their respective full-seeding rates was recommended for areas adjacent to deicing salt applications.

$\mathrm{D}$ eicing salts are applied to sidewalks and roadways to lower the freezing point of water to enhance pedestrian and driving safety during freezing weather. Commercial deicing salts often are applied as rock salt, sodium chloride $(\mathrm{NaCl})$, magnesium chloride $\left(\mathrm{MgCl}_{2}\right)$, or other soluble salts. Sodium chloride is the most commonly used deicing salt with an estimated annual application of 8 to 12 million tons in the United States (Fischel, 2001). Although the fate and movement of deicing salts after their application is not well understood, significant amounts of salt accumulate in adjacent soils covered by lawns and other vegetation (Bryson and Barker, 2002; Viskari and Karenlampi, 2000), and large amounts also runoff into water ways via storm drains and other mechanisms (Cunningham et al., 2008; Godwin et al., 2003; Jackson and Jobbagy, 2005; Kaushall et al., 2005).

This study was funded by the Hatch Project ND01558.

${ }^{1}$ College of Horticulture and Garden, Yangtze University, Jingzhou, Hubei 434025, China

${ }^{2}$ Department of Plant Sciences, North Dakota State University, Fargo, ND 58108

${ }^{3}$ Corresponding author. E-mail: deying.li@ndsu.edu.
Salts remaining in soil can be detrimental to landscape plants including turfgrass (Brod and Preusse, 1980).

Different strategies have been proposed to remedy problems associated with deicing salts, such as leaching, improved drainage, and using salt-tolerant species (Rieke, 1976). Butler et al. (1974) suggested that ALK, desert saltgrass (Distichlis stricta), and weeping ALK (Puccinellia distans) could be used in deicing-salt-affected areas in the northern region of the United States. Minner and Bingaman (1998) investigated injury levels caused by different deicing salts on $\mathrm{KB}$. They concluded that urea and rock salts produced more turf injury than calcium chloride $\left(\mathrm{CaCl}_{2}\right)$, potassium chloride $(\mathrm{KCl})$, urea/ $\mathrm{CaCl}_{2} \quad(30 \% / 70 \%)$, or $\mathrm{NaCl} / \mathrm{KCl}(50 \% / 50 \%)$ following applications of equal rates. After evaluating spring survival levels of $75 \mathrm{cool}$-season turfgrass cultivars following deicing salt treatments during cold weather at four locations in Minnesota, Friell et al. (2011) reported that cultivars of ALK performed best at the MnROAD research facility (Albertville, MN), whereas 'Shoreline' slender creeping RF (Festuca rubra ssp. litoralis), 'Navigator' strong creeping RF (F. rubra ssp. rubra), and some advanced populations of sheep fescue ( $F$. ovina) from the University of Minnesota turfgrass breeding program were among the most salt tolerant at the Roselawn Cemetery (St. Paul, MN).

Ecological and population biological studies have shown that using a blend of cultivars may produce a turf canopy that is more tolerant to stressful environmental conditions than stands of single cultivars (Chen et al., 1997). The same results were observed with a mixture of different species (Ebdon and Skogley, 1985; Gibeault et al., 1993; Horgan et al., 2007; Hunt and Dunn, 1993; Juska and Hanson, 1959). Information is lacking on the shifts of population dynamics of cool-season grass mixtures caused by deicing salt applications and management. Turfgrass managers and seed companies can use such information to determine the optimal seed ratio of different species in a mixture that will result in a balanced population and maximum turf quality under the influence of deicing salts. Since KB and RF are used widely in temperate and cold regions of the United States as home lawn and landscape turf, and ALK offers salt tolerance, mixtures of these species may improve the overall adaptation and turf quality under saline stress. The objective of this study was to determine the optimum ratios of $\mathrm{KB}, \mathrm{RF}$, and ALK for lawn quality subjected to frequent applications of deicing salts.

\section{Materials and methods}

The experiments were conducted at the North Dakota State Agricultural Experiment Station in Fargo. The soil was a Fargo-Ryan silty

\begin{tabular}{llll}
\hline $\begin{array}{l}\text { Units } \\
\begin{array}{l}\text { To convert U.S. to SI, } \\
\text { multiply by }\end{array}\end{array}$ & U.S. unit & SI unit & $\begin{array}{l}\text { To convert SI to U.S., } \\
\text { multiply by }\end{array}$ \\
\hline 0.3048 & $\mathrm{ft}$ & $\mathrm{m}$ & 3.2808 \\
2.54 & inch(es) & $\mathrm{cm}$ & 0.3937 \\
1.1209 & $\mathrm{lb} / \mathrm{acre}$ & $\mathrm{kg} \cdot \mathrm{ha}^{-1}$ & 0.8922 \\
0.9072 & ton $(\mathrm{s})$ & $\mathrm{Mg}$ & 1.1023
\end{tabular}


clay [(fine, montmorillonitic, frigid Vertic Haplaquall)-(fine, montmorillonitic, Typic Natraquoll)], with a soil particle size composition of $2 \%$ sand, $46 \%$ silt, and $52 \%$ clay in the top 6 inches. Soil $\mathrm{pH}$ was 7.9 , and $\mathrm{P}$ and $\mathrm{K}$ contents were 120 and $380 \mathrm{lb} /$ acre, respectively, using Mehlich 3 extractant. Soil Na content was $46 \mathrm{lb} /$ acre. The lawn mixture was composed of the following three species: $\mathrm{KB}$, 'Salty' ALK, and 'Smirna' RF. Kentucky bluegrass was a blend of 'Park' and 'Dragon' in 1:1 gravimetric ratio (Rivard Seed, East Grandforks, MN). The amount of $\mathrm{KB}$ in the three-way mix was based on a single full-seeding rate of $150 \mathrm{lb} /$ acre adjusted with $85 \%$ and $80 \%$ PLS for 'Park' and 'Dragon', respectively. The amount of ALK in the three-way mix was based on a single full-seeding rate of $150 \mathrm{lb} /$ acre adjusted for PLS of $85 \%$. The amount of RF in the three-way mix was based on a single full-seeding rate of 300 $\mathrm{lb} /$ acre adjusted for PLS of $92 \%$. The component of each species in the final mixture were at six different percentages with respect to its single fullseeding rate, $0 \%, 20 \%, 40 \%, 60 \%$, $80 \%$, and $100 \%$. Therefore, a total of 21 seed mixtures were generated based on the simplex-lattice design with three six-level factors (Cornell, 2002). The seed mixtures were arranged in a split-plot design. Three deicing salt rates, $0,160,320 \mathrm{lb} /$ acre, were whole plot treatments arranged in randomized complete block design with three replicates. The 21 seed mixtures were assigned randomly to deicing-salt plots as subplots, each measuring $5 \times 8 \mathrm{ft}$.

The deicing salt mix (Quad Release $^{\circledR}$; Spring Valley, Jackson, WI) contained $90 \% \mathrm{NaCl}, 5 \% \mathrm{KCl}, 2.5 \%$ $\mathrm{MgCl}_{2}, 1.5 \% \mathrm{CaCl}_{2}$, and $1 \%$ calcium magnesium acetate (CaMg acetate) by weight. The product was applied biweekly at 0,20 , or $40 \mathrm{lb} /$ acre in October and November during the year of establishment and in April, May, October, and November during the following 2 years for an annual total of 0,160 , and $320 \mathrm{lb} / \mathrm{acre}$. The deicing salt mix was applied using a drop spreader (model SSD; The Andersons, Maumee, $\mathrm{OH}$ ). The $320-\mathrm{lb} /$ acre rate was the median of an estimated 200 to $800 \mathrm{lb} /$ acre $\mathrm{NaCl}$ annual addition to the 0 to 5.5-inch depth of soil within $10 \mathrm{ft}$ distance of sidewalks in Poughkeepsie, NY (Cunningham et al., 2008).

Table 1. Turfgrass visual quality of mixtures of 'Park' and 'Dragon' Kentucky bluegrass (KB), 'Salty' alkaligrass (ALK), and 'Smirna' creeping red fescue (RF) as affected by deicing salts and seed ratio over a 2 -year period.

\begin{tabular}{|c|c|c|c|}
\hline & & Turf quality(1-9 scale $)^{\mathrm{z}}$ & NDVI $^{y}$ \\
\hline \multicolumn{4}{|c|}{ Deicing salt $(\mathrm{lb} / \text { acre } / \text { year })^{\mathrm{x}}$} \\
\hline 0 & & $6.5 \mathrm{a}^{\mathrm{w}}$ & $0.70 \mathrm{a}$ \\
\hline 160 & & $6.2 \mathrm{ab}$ & $0.69 \mathrm{a}$ \\
\hline 320 & & $6.1 \mathrm{~b}$ & $0.68 \mathrm{a}$ \\
\hline \multicolumn{4}{|l|}{ Seed mixture ${ }^{\mathrm{v}}$} \\
\hline $100 \% \mathrm{RF}$ & & $7.0 \mathrm{c}$ & $0.72 \mathrm{a}$ \\
\hline $100 \% \mathrm{~KB}$ & & $6.6 \mathrm{~d}$ & $0.69 \mathrm{cde}$ \\
\hline $100 \%$ ALK & & $4.4 \mathrm{i}$ & $0.61 \mathrm{i}$ \\
\hline $80 \% \mathrm{RF}+20 \% \mathrm{~A}$ & & $6.5 \mathrm{de}$ & $0.70 \mathrm{bcd}$ \\
\hline $60 \% \mathrm{RF}+40 \% \mathrm{~A}$ & & $6.1 \mathrm{fg}$ & $0.68 \mathrm{cdefg}$ \\
\hline $40 \% \mathrm{RF}+60 \% \mathrm{~A}$ & & $5.9 \mathrm{gh}$ & $0.68 \mathrm{defg}$ \\
\hline $20 \% \mathrm{RF}+80 \% \mathrm{~A}$ & & $5.8 \mathrm{hi}$ & $0.66 \mathrm{fg}$ \\
\hline $80 \% \mathrm{RF}+20 \% \mathrm{~K}$ & & $7.2 \mathrm{ab}$ & $0.73 \mathrm{a}$ \\
\hline $60 \% \mathrm{RF}+40 \% \mathrm{~K}$ & & $7.4 \mathrm{a}$ & $0.72 \mathrm{a}$ \\
\hline $40 \% \mathrm{RF}+60 \% \mathrm{~K}$ & & $7.3 \mathrm{a}$ & $0.72 \mathrm{ab}$ \\
\hline $20 \% \mathrm{RF}+80 \% \mathrm{~K}$ & & $7.0 \mathrm{bc}$ & $0.72 \mathrm{ab}$ \\
\hline $80 \% \mathrm{~KB}+20 \% \mathrm{~A}$ & & $5.8 \mathrm{hi}$ & $0.66 \mathrm{fg}$ \\
\hline $60 \% \mathrm{~KB}+40 \% \mathrm{~A}$ & & $5.6 \mathrm{ij}$ & $0.64 \mathrm{gh}$ \\
\hline $40 \% \mathrm{~KB}+60 \% \mathrm{~A}$ & & $5.5 \mathrm{j}$ & $0.64 \mathrm{~h}$ \\
\hline $20 \% \mathrm{~KB}+80 \% \mathrm{~A}$ & & $5.1 \mathrm{k}$ & $0.63 \mathrm{hi}$ \\
\hline $60 \% \mathrm{RF}+20 \% \mathrm{~K}$ & $\%$ ALK & $6.5 \mathrm{de}$ & $0.70 \mathrm{abc}$ \\
\hline $40 \% \mathrm{RF}+40 \% \mathrm{~K}$ & $\%$ ALK & $6.2 \mathrm{f}$ & 0.69 cde \\
\hline $40 \% \mathrm{RF}+20 \% \mathrm{~K}$ & $\%$ ALK & $6.2 \mathrm{f}$ & $0.69 \mathrm{cde}$ \\
\hline $20 \% \mathrm{RF}+60 \% \mathrm{~K}$ & $\%$ ALK & $6.3 \mathrm{ef}$ & $0.68 \mathrm{cdefg}$ \\
\hline $20 \% \mathrm{RF}+40 \% \mathrm{~K}$ & $\%$ ALK & $5.8 \mathrm{hi}$ & $0.68 \mathrm{efg}$ \\
\hline $20 \% \mathrm{RF}+20 \% \mathrm{~K}$ & $\%$ ALK & $5.8 \mathrm{hi}$ & $0.67 \mathrm{efg}$ \\
\hline \\
\hline \multicolumn{4}{|c|}{$\begin{array}{l}\text { ANOVA } \\
\qquad F(P>F)\end{array}$} \\
\hline Deicing salt (S) & 2 & $6.99(0.049)^{*}$ & $4.26(0.10)$ \\
\hline Seed mixture $(M)$ & 20 & $78.52(<0.0001) * * *$ & $14.34(<0.0001) * * *$ \\
\hline$S \times M$ & 40 & $1.78(0.004)^{* *}$ & $0.6(0.97)$ \\
\hline
\end{tabular}

${ }^{2}$ Turfgrass visual quality (a combination of density, color and uniformity) was evaluated following the Turfgrass Evaluation Program (NTEP) guidelines (NTEP, 2000) on a 1 to 9 scale, with $1=$ dead grass, $6=$ minimum acceptable, and $9=$ the best.

${ }^{y}$ Normalized difference vegetation index was calculated from the reflectance data for near IR light at $770 \mathrm{~nm}$ and red light at $660 \mathrm{~nm}$.

${ }^{x}$ Deicing salt rates were $160 \mathrm{lb} /$ acre $\left(179.4 \mathrm{~kg} \cdot \mathrm{ha}^{-1}\right)$ and $320 \mathrm{lb} /$ acre $\left(358.7 \mathrm{~kg} \cdot \mathrm{ha}^{-1}\right)$.

wTreatment means are from 24 readings. Means within one main effect followed by same letter are not significant at 0.05 Plevel.

"The seed ratio in the mixture was based on percentages of the full-seeding rate of each species, where KB and ALK was $150 \mathrm{lb} /$ acre $\left(168.1 \mathrm{~kg} \cdot \mathrm{ha}^{-1}\right)$, and RF was $300 \mathrm{lb} /$ acre $\left(336.3 \mathrm{~kg} \cdot \mathrm{ha}^{-1}\right)$, all adjusted by the respective pure live seed rate.

For the first experiment, the turfgrass mixtures were seeded in Aug. 2009. Starter fertilizer was applied at an $\mathrm{N}$ rate of $50 \mathrm{lb} /$ acre from $29 \mathrm{~N}-0.9 \mathrm{P}-2.5 \mathrm{~K}$ (The Andersons). The grass received $150 \mathrm{lb} /$ acre of $\mathrm{N}$ and $100 \mathrm{lb} /$ acre of K annually during the 2010 and 2011 growing season, and was mowed at 2.5-inch height weekly with clippings returned. After establishment, irrigation was applied only to prevent wilting.

Turfgrass visual quality (VQ), species component in the canopy, and the turfgrass spectrum radiance were measured four times in May, July, and Oct. 2010 and in Oct. 2011 for the first experiment. Turfgrass VQ was evaluated on a 1 to 9 scale following the National Turfgrass Evaluation Program guidelines (NTEP, 2000), with 1 being dead grass, 6 as minimum acceptable, and 9 as the best. The species component in turf cover was assessed using a self-fabricated point interception device based on the principle of point analysis (Levy and Madden, 1933). One hundred interceptions were measured per subplot and the coverage was calculated in four categories (KB, RF, ALK, and bare ground). The spectrum radiance was measured by scanning each subplot at $3 \mathrm{ft}$ aboveground with a handheld data collection and mapping unit (model 505 GreenSeeker; Trimble, Hamilton, IN). The 
Table 2. Statistics of the turfgrass visual quality of 'Park' and 'Dragon' kentucky bluegrass (KB), 'Salty' alkaligrass (ALK), and 'Smirna' creeping red fescue (RF) with the seed mixture ratios generated from simplex-lattice design. The results were from the populations without and with $320 \mathrm{lb} /$ acre $\left(358.7 \mathrm{~kg} \cdot \mathrm{ha}^{-1}\right)$ per year deicing salts application over a 2 -year period.

\begin{tabular}{|c|c|c|c|c|c|c|c|c|c|}
\hline \multicolumn{10}{|c|}{ ANOVA for turfgrass visual quality } \\
\hline \multirow[b]{2}{*}{ Source } & \multirow[b]{2}{*}{ df } & \multicolumn{4}{|c|}{$0 \mathrm{lb} /$ acre per yr } & \multicolumn{4}{|c|}{$320 \mathrm{lb} /$ acre per yr } \\
\hline & & $S^{y}$ & MS $^{\mathbf{y}}$ & $F$ & $P>F$ & SS & MS & $F$ & $P>F$ \\
\hline ALK & 1 & 134.96 & 134.96 & 671.35 & $<0.0001$ & 136.86 & 136.86 & 865.05 & $<0.0001$ \\
\hline RF & 1 & 361.47 & 361.47 & 1798.13 & $<0.0001$ & 304.76 & 304.76 & 1926.25 & $<0.0001$ \\
\hline $\mathrm{KB} \times \mathrm{ALK}$ & 1 & 2.42 & 2.42 & 12.03 & 0.001 & 0.13 & 0.13 & 0.79 & 0.374 \\
\hline
\end{tabular}

Fit statistics for turfgrass visual quality

\begin{tabular}{|c|c|c|c|c|}
\hline \multirow[b]{2}{*}{ Parameter } & \multicolumn{2}{|c|}{$0 \mathrm{lb} /$ acre per year } & \multicolumn{2}{|c|}{$320 \mathrm{lb} /$ acre per year } \\
\hline & Master model & Predictive model & Master model & Predictive model \\
\hline$R^{2}$ & 0.78 & 0.78 & 0.73 & 0.73 \\
\hline Adjusted $R^{2}$ & 0.77 & 0.78 & 0.72 & 0.72 \\
\hline $\mathrm{RMSE}^{\mathrm{y}}$ & 0.448 & 0.447 & 0.398 & 0.397 \\
\hline $\mathrm{CV}(\%)^{\mathrm{y}}$ & 8.51 & 8.48 & 7.82 & 7.81 \\
\hline
\end{tabular}

${ }^{2}$ Turfgrass visual quality (a combination of density, color, and uniformity) was evaluated following the Turfgrass Evaluation Program (NTEP) guidelines (NTEP, 2000) on a 1 to 9 scale, with 1 being dead grass, 6 as minimum acceptable, and 9 as the best.

ySS = sum of squares, MS = mean squares, RMSE $=$ root mean square of standard error, $\mathrm{CV}=$ coefficient of variation

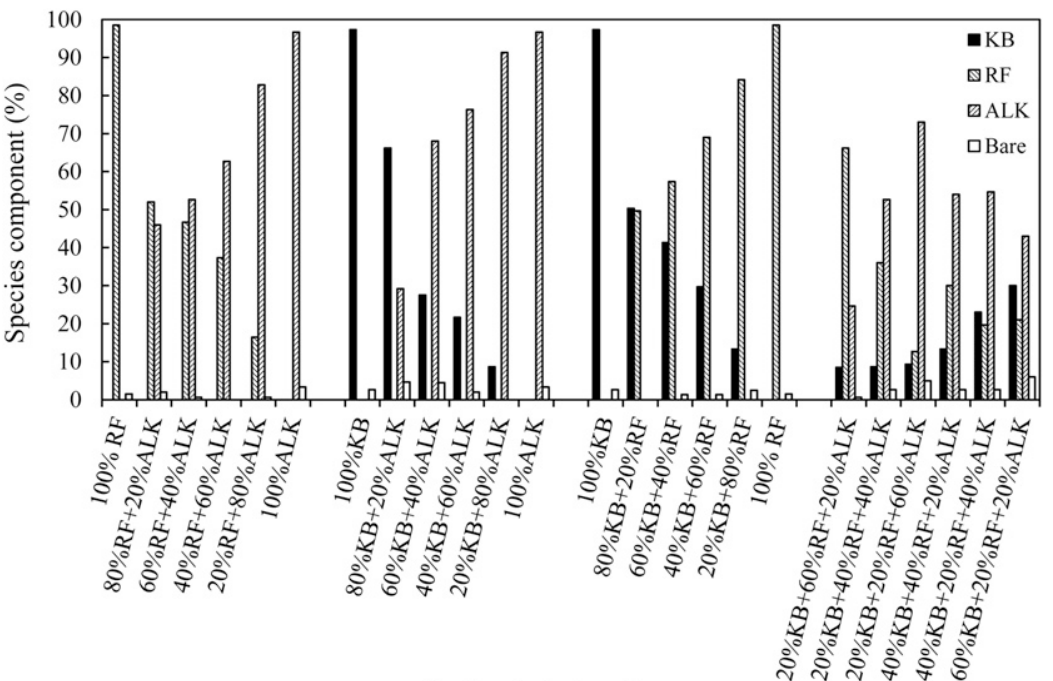

Seed ratio in the mixture

Fig. 1. The botanical component of turfgrass mixtures containing kentucky bluegrass (KB), alkaligrass (ALK), and creeping red fescue (RF) with each species at six different percentages based on the full-seeding rate of 150, 150, and $300 \mathrm{lb}$ / acre, respectively. The measurements shown were from the first spring following fall seeding without deicing salt applications. The standard deviations for $\mathrm{KB}, \mathrm{RF}$, $\mathrm{ALK}$, and bare ground were $0.27,0.27,0.23$, and 0.03 , respectively; $1 \mathrm{lb} /$ acre $=$ $1.1209 \mathrm{~kg} \cdot \mathrm{ha}^{-1}$.

reflectance data for near-infrared light (NIR) at $770 \mathrm{~nm}$ and red light (red) at $660 \mathrm{~nm}$ were used to calculate normalized difference vegetation index (NDVI) using the following formula: $\mathrm{NDVI}=(\mathrm{NIR}-\mathrm{red}) /(\mathrm{NIR}+\mathrm{red})$.

The experiment was repeated at a different location on the same farm station with new turfgrass establishment in Aug. 2010. Measurements in the second experiment were conducted in May, July, and Oct. 2011 and in Oct. 2012 following the same methods used in the first experiment.

Homogeneity of means and variability between two experiments were tested with the Hovtest procedure in SAS (version 9.2; SAS Institute, Cary, NC). The data were subjected to analysis of variance using mixed procedures in SAS (version 9.2) with the replication blocks treated as a random variable. The means of all 21 mixtures were compared using the Tukey's method. For seed ratio optimization, the average data across the growing seasons in each experiment were subjected to statistical analysis using the procedures for simplex-lattice mixture design in SAS (version 9.2).

\section{Results and discussion}

The two experiments showed homogeneous variance, therefore, the data were combined in statistical analysis. Deicing salt rate, seed mixtures, and the interaction between deicing salt rate and seed mixtures all had significant effects on turfgrass VQ (Table 1). With data averaged across seed mixtures to test the main effects of deicing applications, the VQ value was 6.1 for the deicing salt rate of $320 \mathrm{lb} /$ acre, lower than that of 6.5 for the untreated control. No VQ difference was detected between the 160-lb/acre rate and the untreated control (Table 1). The binary mixtures of $\mathrm{KB}$ and $\mathrm{RF}$ with RF contributing more than $40 \%$ of its full-seeding rate in the mixture demonstrated highest VQ among the 21 mixtures. The ALK monostand and the binary mixtures of $\mathrm{KB}$ and ALK with ALK contribute more than $40 \%$ of its full-seeding rate in the mixture had lower VQ than other mixtures (Table 1). 


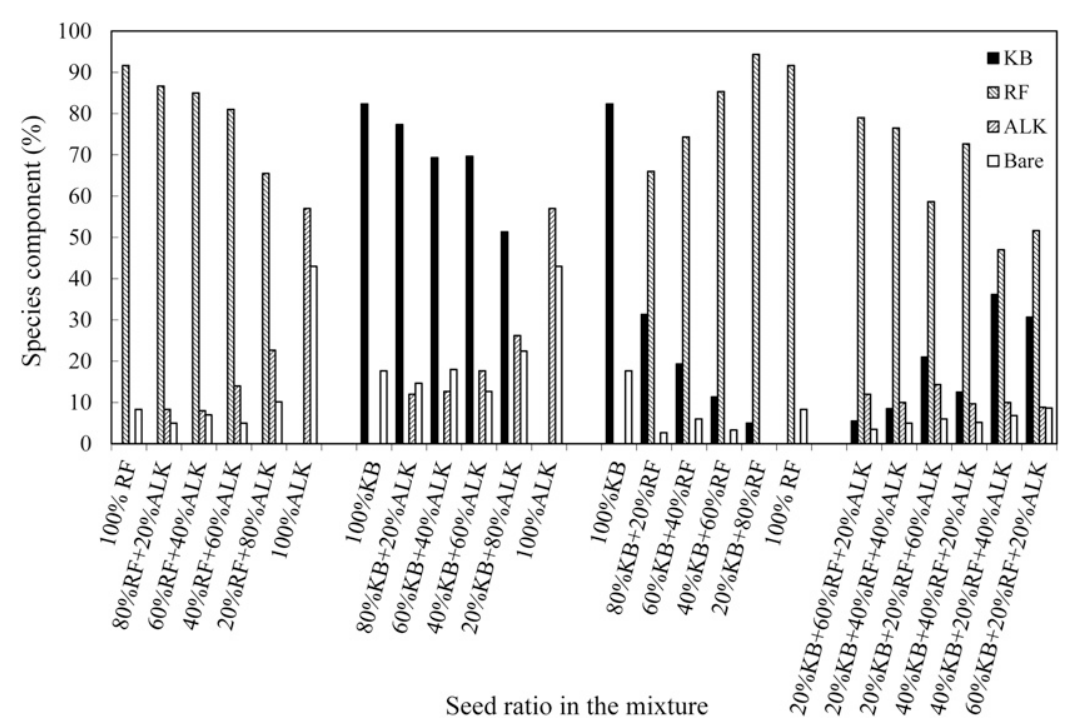

Fig. 2. The botanical component of turfgrass mixtures containing kentucky bluegrass (KB), alkaligrass (ALK), and creeping red fescue (RF) with each species at six different percentages based on the full-seeding rate of 150,150 , and $300 \mathrm{lb} /$ acre, respectively. The measurements shown were from the end of a 2 -year study for populations receiving deicing salt at $320 \mathrm{lb} /$ acre per year. The standard deviations for $K B, R F, A L K$, and bare ground were $0.3,0.17,0.17$, and 0.11 , respectively; $1 \mathrm{lb} /$ acre $=1.1209 \mathrm{~kg} \cdot \mathrm{ha}^{-1}$.

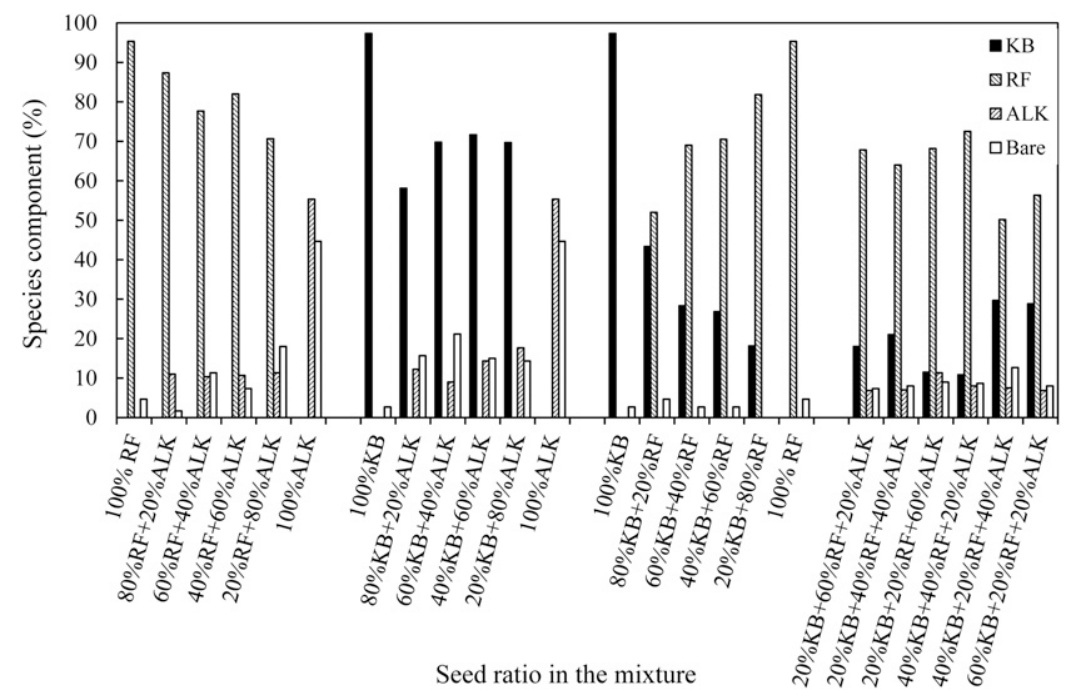

Fig. 3. The botanical component of turfgrass mixtures containing kentucky bluegrass (KB), alkaligrass (ALK), and creeping red fescue (RF) with each species at six different percentages based on the full-seeding rate of 150,150 , and $300 \mathrm{lb} /$ acre, respectively. The measurements shown were from the population without deicing salt applications at the end of a 2 -year study. The standard deviations for $\mathrm{KB}, \mathrm{RF}, \mathrm{ALK}$, and bare ground were $0.3,0.19,0.17$, and 0.14 , respectively; $1 \mathrm{lb} /$ acre $=1.1209 \mathrm{~kg} \cdot \mathrm{ha}^{-1}$.

This indicated that VQ in general was higher with the high RF and low ALK initial seeding ratio under the management regime of this study.

The average NDVI was not different among deicing salt rates, indicating that this parameter was not sensitive to the salinity stress subjected to these plants. However, seed mixtures
Unlike multiple comparisons, statistical output from the simplexlattice mixture design generates model prediction for VQ of the lawn mixtures based on main effects and interactions (Table 2). Without deicing salt application, the prediction model using only the significant effects was

$$
\begin{aligned}
\mathrm{VQ}= & 5.99 \mathrm{~KB}+3.78 \mathrm{ALK}+6.20 \mathrm{RF} \\
& -2.09 \mathrm{~KB} \times \mathrm{ALK}+1.25 \mathrm{~KB} \\
& \times \mathrm{RF}\left(\text { adjusted } R^{2}=0.78\right) .
\end{aligned}
$$

The predicted optimum turfgrass VQ was 7.2 with a $95 \%$ confident interval between 7.1 and 7.4. To achieve this quality, the predicted optimum seed ratio of $\mathrm{KB}$ was $39.3 \%$ of its single full-seeding rate, RF was $\mathbf{5 5 . 9 \%}$ of its single full-seeding rate, and ALK was $4.8 \%$ of its single full-seeding rate.

For the VQ of the mixtures that received deicing salts at $320 \mathrm{lb} /$ acre, the prediction model using only the significant effects (Table 2) was

$$
\begin{aligned}
\mathrm{VQ}= & 5.07 \mathrm{~KB}+3.76 \mathrm{ALK}+5.71 \mathrm{RF} \\
& -2.38 \mathrm{~KB} \times \mathrm{RF}+1.19 \mathrm{ALK} \\
& \times \mathrm{RF}\left(\text { adjusted } R^{2}=0.72\right) .
\end{aligned}
$$

The predicted optimum VQ was 7.0 with a $95 \%$ confident interval of 6.8 to 7.2 , where the predicted optimum seed ratio for $\mathrm{KB}$ was $48.3 \%$ of its single full-seeding rate, RF was $51.7 \%$ of its single full-seeding rate, and ALK was $0.0 \%$ of its single fullseeding rate.

Species and their interactions contributed differently to VQ with different deicing salt application rates. Therefore, competitions or synergies among the three species were affected by management practice as well as salt stress. The coefficient of the $\mathrm{KB} \times$ ALK term in the VQ prediction model was negative when no deicing salts were applied, but it was not significant with deicing salt applications at $320 \mathrm{lb} /$ acre. Also, ALK $\times$ RF interaction did not contribute to the VQ model for the populations without deicing salts (Table 2). Although the ALK monostand showed better adaptation than KB under low maintenance conditions (Friell et al., 2011), it did not appear to enhance turf quality in the mixtures containing $\mathrm{KB}$ and $\mathrm{RF}$ in this study when deicing salts were applied. Ebdon and Skogley (1985) also reported that the quality of turf stands maintained under low 
fertility and drought rested primarily on the ability of perennial ryegrass (Lolium perenne) or RF in the mixture to outperform $\mathrm{KB}$ because the RF was more competitive under stress. The inclusion of ALK did not improve the turf quality in the mixtures subjected to frequent application of deicing salts and maintained at the 2.5 -inch mowing height and fertility level in this study.

Despite the initial seed ratios in the mixtures, ultimately the turf VQ is dictated by the component of canopy of different species at equilibrium. The species component present in the turfgrass canopy during the spring immediately following fall seeding showed that the percentage of each species was in proportion to the initial seed ratios (Fig. 1). Compared with the untreated first spring population base line, the population shifted after 2 years either with deicing salt applications at $320 \mathrm{lb} /$ acre (Fig. 2) or without deicing salt applications (Fig. $3)$. At the end of 2-year study, the populations received deicing salts at $320 \mathrm{lb} /$ acre per year showed an increase of $\mathrm{KB}$ mainly in the three-way mixtures or its binary mixtures with ALK compared with the population without deicing salt applications (Fig. $2)$. Similarly, in the deicing-salttreated populations at $320 \mathrm{lb} /$ acre per year, RF increased in three-way mixtures or its binary mixtures with $\mathrm{ALF}$ and $\mathrm{KB}$ when the $\mathrm{KB}$ seed ratio was either very low $(20 \%)$ or very high (80\%) (Fig. 2). These results indicated that RF was more competitive and could overtake the $\mathrm{KB}$ if the seed ratio of $\mathrm{KB}$ was equal to or less than $20 \%$, which concur with the results of Ebdon and Skogley (1985).

On the basis of the predicted optimum initial seeding ratio from the simplex-lattice analysis, an approximation of the botanical components could be made from Figs. 2 and 3 . This approximation showed that for an optimum VQ, the $\mathrm{KB}$ cover would range from $11 \%$ to $28 \%$, RF cover range from $69 \%$ to $73 \%$, and ALK cover range $<5 \%$ with no deicing salt applications (Fig. 3). Similarly, for an optimum VQ with deicing salt applications at $320 \mathrm{lb} /$ acre per year, $\mathrm{KB}$ cover would range from $11 \%$ to $19 \%$ and RF from $74 \%$ to $85 \%$ in a binary mixture (Fig. 2). This information is helpful to guide seed ratios because the weight-based ratios may change due to the changes in PLS of these species.

In conclusion, species components in the 21 populations generated with simplex-lattice design from $\mathrm{KB}$, RF, and ALK shifted over a 2-year period after fall establishment. Such shifts happened regardless of the applications of deicing salts. However, the shift in species component showed noticeable differences with deicing salts at $320 \mathrm{lb} /$ acre, which had less ALK coverage at the end of study. Despite the salinity tolerance reported for ALK from previous research, under the current management regime, especially the relatively low mowing height of 2.5 inches, ALK did not contribute to the turf quality improvement in the mixtures subjected to frequent deicing salt applications. Under a typical home lawn maintenance regime and with its quality expectation, an initial seed mixture of $\mathrm{KB}$ and $\mathrm{RF}$ composed of $48 \%$ and $52 \%$ of their respective single full-seeding rates of 150 and $300 \mathrm{lb} /$ acre was expected to generate maximized and acceptable turf quality. Further research should focus on the potentials of mixing other species with good salinity tolerance such as turf type tall fescue (Festuca arundinacea).

\section{Literature cited}

Brod, H.G. and H.U. Preusse. 1980. The influence of deicing salts on soil and turf cover. Intl. Turfgrass Soc. Res. J. 3:461-468.

Bryson, G.M. and A.V. Barker. 2002. Sodium accumulation in soils and plants along Massachusetts roadsides. Commun. Soil Sci. Plant Anal. 33:67-78.

Butler, J.D., J.L. Fults, and G.D. Sanks. 1974. Review of grasses for saline and alkali areas. Intl. Turfgrass Soc. Res. J. 2:551-556.

Chen, Y., J.L. Eggens, and K. Carey. 1997. Stress response of single and multiple cultivar populations of bent (Agrostis spp.). Intl. Turfgrass Soc. Res. J. 8:639-651.

Cornell, J.A. 2002. Experiments with mixtures: Designs, models, and the analysis of mixture data. 3rd ed. Wiley, Hoboken, NJ.

Cunningham, M.A., E. Snyder, D. Yonkin, M. Ross, and T. Elson. 2008. Accumulation of deicing salts in soils in an urban environment. Urban Ecosyst. 11:17-31.

Ebdon, J.S. and C.R. Skogley. 1985. Performance of coolseason turfgrass in mixture under reduced maintenance. Intl. Turfgrass Soc. Res. J. 5:275-283.
Fischel, M. 2001. Evaluation of selected deicers based on a review of the literature. Colorado Dept. Transportation Res. Branch, Rpt. No. CDOT-DTD-R-200115. The SeaCrest Group. Louisville, CO.

Friell, J., E. Watkins, and B. Horgan. 2011. Differential salt tolerance of 75 cool-season turfgrass cultivars for sustainable roadsides. Amer. Soc. Agron.-Crop Sci. Soc. Amer.-Soil Sci. Soc. Amer. Intl. Annu. Mtg. 16-19 Oct. 2011. San Antonio, TX. p. 66230. (Abstr.).

Gibeault, V.A., S.T. Cockerham, and R. Autio. 1993. An evaluation of tall fescue and kentucky bluegrass mixes. Intl. Turfgrass Soc. Res. J. 7:905-909.

Godwin, K.S., S.D. Hafner, and M.F. Buff. 2003. Long-term trends in sodium and chloride in the Mohawk River, New York: The effect of fifty years of road-salt application. Environ. Pollut. 124:273-281.

Horgan, B., A. Hollman, E. Koeritz, and J. Stier. 2007. Fine fescues and colonial bentgrasses for fairways: With proper fertility treatments, some fine fescues show promise for fairways use. Golf Course Mgt. 75(5):112-117.

Hunt, K.L. and J.H. Dunn. 1993. Compatibility of kentucky bluegrass and perennial ryegrass with tall fescue in transition zone turfgrass mixtures. Agron. J. 85:211-215.

Jackson, R.B. and E.G. Jobbagy. 2005. From icy roads to salty streams. Proc. Natl. Acad. Sci. USA 102:14487-14488.

Juska, F.V. and A.A. Hanson. 1959. Evaluation of cool-season turfgrass alone and in mixtures. Agron. J. 12:597-600.

Kaushall, S., P. Groffman, G. Liken, K. Belt, W. Stack, V. Kelly, L. Band, and G. Fisher. 2005. Increased salinization of freshwater in the northeastern United States. Proc. Natl. Acad. Sci. USA 102:13517-13520.

Levy, E.B. and E.A. Madden. 1933. A point method of pasture analysis. N.Z. J. Agr. 46:267-279.

Minner, D. and B.R. Bingaman. 1998. The effect of deicing chemicals on turfgrass, $\mathrm{p}$. 119-126. In: 1998 Iowa Turfgrass Research Report. Iowa State Univ. Ext., Ames.

National Turfgrass Evaluation Program. 2000. NTEP turfgrass evaluation guidelines. 25 Sept. 2014. <http://www.ntep.org/ cooperator.htm>.

Rieke, P.E. 1976. Winter deicing salts and their effects on turf. Proc. 46th Annu. Michigan Turfgrass Conf. p. 51-53.

Viskari, E.L. and L. Karenlampi. 2000. Road scots pine as an indicator of deicing salt use-a comparative study from two consecutive winters. Water Air Soil Pollut. 122:405-409. 